
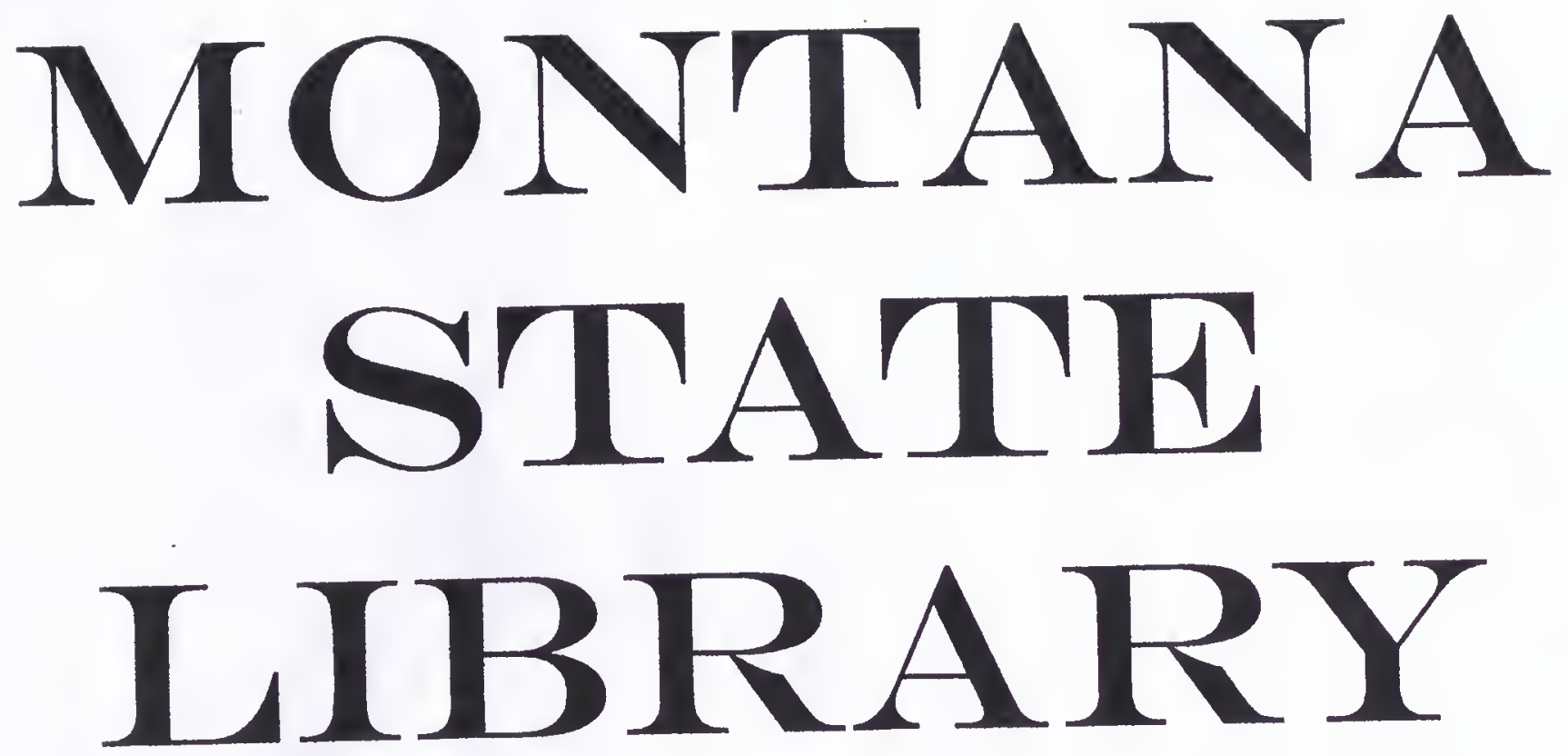

This "cover" page added by the Internet Archive for formatting purposes 



\title{
STATUS REPORT ON SENSITIVE LADY'S SLIPPER ORCHIDS (CYPRIPEDIUM CALCEOLUS VAR. PARVIFLORUM \\ AND CYPRIPEDIUM PASSERINUM) ON THE KOOTENAI NATIONAL FOREST
}

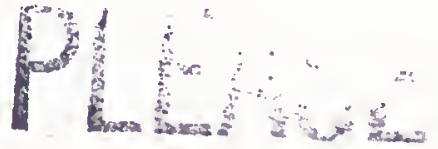 \\ 等 \\ By: \\ Jim Vanderhorst \\ Montana Natural Heritage Program \\ State Library \\ 1515 East Sixth Avenue \\ Helena, Montana 59620-1800 \\ For:

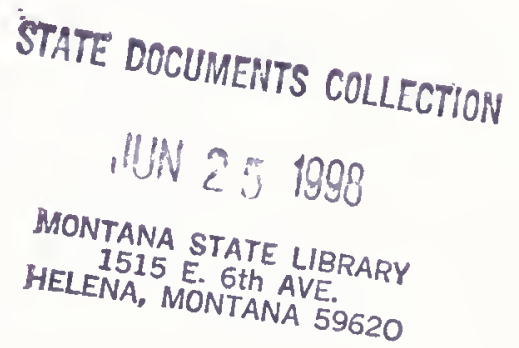 \\ Kootenai National Forest \\ 506 U.S. Highway 2 West \\ Libby, Montana 59923
}

Agreement no. 11011454002

February 1996 


\section{This is an abridged report}

For the full report please contact:

The Montana Natural Heritage Program

1515 E Sixth Ave

Helena, Montana 59620

406-444-3009 


\section{(C) 1996 Montana Natural Heritage Program}

This document should be cited as follows:

Vanderhorst, J. 1996. Status report on Sensitive lady's slipper orchids (Cypripedium calceolus var. parviflorum and Cypripedium passerinum) on the Kootenai National Forest. Unpublished report to the Kootenai National Forest. Montana Natural Heritage Program, Helena. 27 pp. plus appendices. 


\section{Acknowledgements}

Special thanks are extended to Leslie Ferguson, Lou Kuennen, Dan Leavell, Tobias Spribille and Jack Triepke on the Kootenai National Forest for their time, interest, and expertise. In the Montana Natural Heritage Program, thanks are extended to Bonnie Heidel for coordination and technical contributions, and to Cedron Jones for GIS map production. Funding for this project was provided through a challenge cost-share agreement between the Kootenai National Forest and the Montana Natural Heritage Program. 


\section{Executive Summary}

Surveys in 1995 by Montana Natural Heritage Program and Kootenai National Forest botanists located five new occurrences of small yellow lady's slipper (Cypripedium calceolus var.

parviflorum) and two new occurrences of sparrow's egg lady's slipper (‥ passerinum) on the Kootenai National Forest. There are now 15 occurrences of $C$. calceolus var. parviflorum and 6 occurrences of $\underline{C}$. passerinum known from the Forest. The populations of both species on Kootenai National Forest are potential conservation strategy contributions from a state and regional office perspective in terms of their distribution and/or population sizes. Populations of these sensitive orchid species are restricted to calcareous wetlands on the Fortine and Libby Ranger Districts. The local distribution of these plants appears to be further restricted by grazing; significant numbers were found only in areas where cattle are excluded. This status report summarizes available species' information to date, augmenting guidebook information as a reference and planning tool. 


\section{Table of Contents}

Acknowledgements $\ldots \ldots \ldots \ldots \ldots \ldots \ldots \ldots \ldots \ldots \ldots \ldots \ldots \ldots \ldots \ldots \ldots \ldots \ldots \ldots$ ii

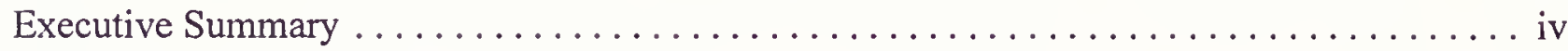

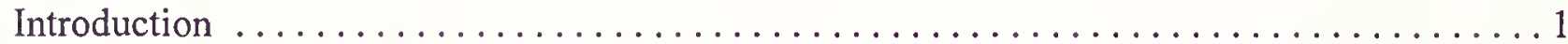

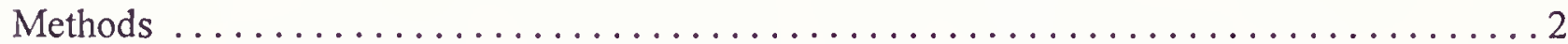

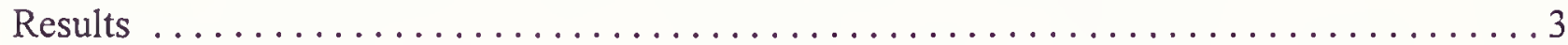

Status Reviews

Cypripedium calceolus var. parviflorum $\ldots \ldots \ldots \ldots \ldots \ldots \ldots \ldots \ldots \ldots$

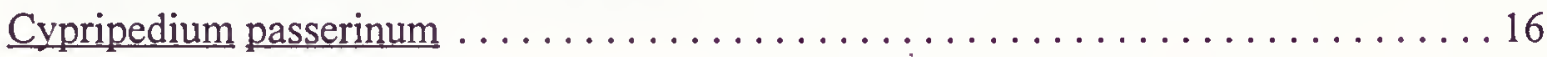

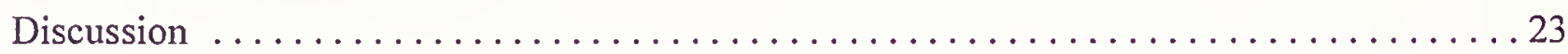

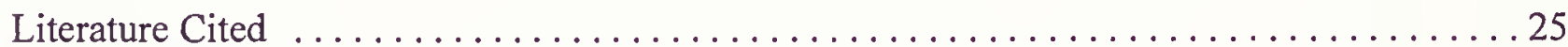

Appendix A. Element Occurrence Records and maps

Appendix B. ECODATA forms

Appendix C. Photographic slides

\section{List of Tables}

Table 1. Occurrences of Sensitive Cypripedium spp. on the Kootenai National Forest .3

\section{List of Figures}

Figure 1. Map of Cypripedium calceolus var. parviflorum sites $\ldots \ldots \ldots \ldots \ldots \ldots \ldots 7$

Figure 2. Map of Cypripedium passerinum sites $\ldots \ldots \ldots \ldots \ldots \ldots \ldots \ldots \ldots \ldots \ldots \ldots \ldots \ldots$ 


\section{Introduction}

This report reviews the status of Sensitive lady's slipper orchid species (Cypripedium calceolus var. parviflorum and $\underline{C}$. passerinum) on the Kootenai National Forest (KNF) as a contribution to rangewide conservation planning and Forest-wide biological evaluations. Significant

populations of these rare orchids have only recently been documented on the KNF and have been found to occupy unique habitats which face many potential threats. This project was initiated to determine the full ecological and geographical distribution of these species on the Forest in order to set up a framework for their conservation.

Small yellow lady's slipper (Cypripedium calceolus var. parviflorum) was first documented from the KNF by a 1973 specimen from Dickey Lake. Recent surveys (Chadde 1989, 1991, Hoitsma 1992) have located several more populations. Sparrow's egg lady's slipper (Cypripedium passerinum) was documented from the KNF for the first time in 1991 by Todd Hoitsma (1992). These species often occur together, along with another Sensitive orchid, round-leaved orchid (Amerorchis rotundifolia, syn. Orchis rotundifolia), and usually grow in moist to wet calcareous soils in the ecotones between spruce forest habitats and wetland communities. Known populations of these three orchids are in the Rocky Mountain Trench portion of the KNF on the Fortine District, and additional populations of $C$. calceolus var. parviflorum alone occur in the vicinity of Libby Dam on the Libby Ranger District. A third species of Sensitive lady's slipper, clustered lady's slipper (Cypripedium fasciculatum), has not been found on the KNF to date although appropriate habitat may exist.

This report compiles known information on Cypripedium calceolus var. parviflorum and $\mathrm{C}$. passerinum from the literature, from the Biological Conservation Database maintained by MTNHP, and from extensive new field surveys and intensive data collection at select sites. Included is information on classification, pending taxonomic changes, morphology, distribution, biology, and ecology, and a discussion of current threats to populations of these plants and conservation management strategies. Consideration of potential for finding $\mathrm{C}$. fasciculatum is included in the Discussion section of this report. Included in appendices are Element Occurrence Records and topographic maps showing the precise locations of populations of sensitive lady's slippers on the KNF, ECODATA from several population sites, and photographic slides of the plants and their habitats. 


\section{Methods}

Available information was compiled and developed into search lists and habitat search images prior to fieldwork. The Biological Conservation Database maintained by MTNHP was queried for known occurrences of sensitive Cypripedium species on the KNF, resulting in nine occurrences of Cypripedium calceolus var. parviflorum and four occurrences of $\mathrm{C}$. passerinum. Knowledgeable Forest personnel and other local individuals were consulted and provided leads of possible Cypripedium sightings which were not entered in the database.

Land type (Kuennen and Gerhardt 1984) and geological (Harrison et al. 1992) maps were used to identify areas with high potential for hosting populations of $\underline{C}$. calceolus var. parviflorum and $\underline{C}$. passerinum based on the presence of limestone formations and/or calcareous soils in conjunction with wetland features. Reports on Sensitive lady's slippers in Montana were consulted to gain insight into the species' biology and ecology and to identify and prioritize research needs (Chadde 1989, 1991, Heidel 1992, Hoitsma 1992, Shelly 1988).

Fieldwork was conducted from late May to early July 1995. Most of the known occurrences of sensitive Cypripedium were revisited to determine population trends and habitat conditions and to gain a search image for the plants and their habitats. Areas throughout the Forest identified as having potential for hosting the Sensitive orchids were searched for new occurrences; a list of areas searched is included in section D.3.d. of the status review for C. calceolus var. parviflorum.

When new occurrences were found or known occurrences were relocated, field survey forms were filled out or Element Occurrence Records updated with the new information on habitat, population numbers, and populations distribution. Voucher specimens of $\mathrm{C}$. calceolus var. parviflorum were taken from large populations, following collection guidelines established by the Montana Native Plant Society (1993), and were sent to a specialist of the genus, Dr. Charles Sheviak (NYS), for verification and to determine if hybridization with $\mathrm{C}$. montanum is occurring at one site. The first set of all collections will be deposited at the herbarium at the University of Montana in Missoula (MONTU), and duplicates will be left with Dr. Sheviak at the State Museum of New York in Albany (NYS) and the Intermountain Research Station (MRC).

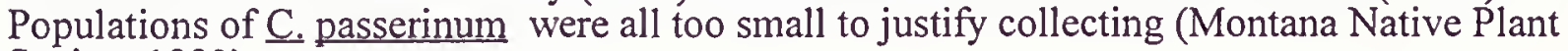
Society 1993).

Specimens of associated vascular plants and bryophytes were collected to refine the habitat circumscription. Moss identifications are being determined by Joe Elliott (Conservation Biology Research, Helena, MT). These moss specimens will be donated to the KNF herbarium in Libby. ECODATA macroplot information, including location linkage, general field data, and plant composition (U.S. Forest Service 1992) was sampled from four population sites. Photographs were taken of the plants and their habitats.

Nearest populations of Cypripedium fasciculatum on the Lolo National Forest in the vicinity of St. Regis were visited to gain insight on that species' habitat requirements and a limited amount of time was spent searching for it in appropriate habitat on the KNF. 


\section{Results}

Range and representative habitats of the two Sensitive lady's slippper species on the KNF were circumscribed, population and habitat trends were documented, and their status was put into a state context augmented by the few new occurrences that were found. I discovered one new population of Cypripedium calceolus var. parviflorum in an unnamed drainage southeast of Libby Dam, and one new occurrence of $\mathrm{C}$. passerinum at Brimstone Creek where $\mathrm{C}$. calceolus var. parviflorum was previously known. Forest botanists from the Fortine Ranger District, Jack Triepke and Tobias Spribille, found four additional populations of $\mathrm{C}$. calceolus var. parviflorum along Lime and Murphy Creeks, near Dickey Lake, and in the foothills of the Whitefish Range above Glen Lake. T. Spribille also found an occurrence of C. passerinum along Magnesia Creek. In addition, one population of $\underline{C}$. calceolus var. parviflorum on Army Corps of Engineers land near Libby Dam which was known by local individuals was verified. Several known populations of undetermined Cypripedium species were relocated and were found to be the relatively common C. montanum. There are now fifteen populations of C. calceolus var. parviflorum and six known populations of $\mathrm{C}$. passerinum on the KNF (Table 1). Cypripedium fasciculatum has not been found on the Forest.

Table 1. Occurrences of Cypripedium calceolus var. parviflorum and C. passerinum on the Kootenai National Forest.

\begin{tabular}{|l|c|c|c|}
\hline & $\begin{array}{l}\text { Fortine } \\
\text { District }\end{array}$ & $\begin{array}{c}\text { Libby } \\
\text { District }\end{array}$ & Total \\
\hline $\begin{array}{l}\text { Cypripedium calceolus var. } \\
\text { parviflorum }\end{array}$ & 12 & 3 & 15 \\
\hline Cypripedium passerinum & 6 & - & 6 \\
\hline
\end{tabular}

The Status Reviews for each of the two Sensitive Cypripedium species which follow this section elaborate the results of the surveys and provide pertinent information from other sources. Included are sections on classification, pending taxonomic changes, formal status, description, geographical distribution, habitat, population demography and biology, land ownership, and management considerations. Throughout the remainder of this report occurrences of Sensitive lady's slippers are referred to by their site names and three digit element occurrence numbers assigned in the Biological Conservation Database. Element Occurrence Records and topographic maps showing the precise location of each population are given in Appendix A. ECODATA forms are included in Appendix B and photographic slides of the plants and their habitats are attached as Appendix C. 


\section{Cypripedium calceolus var. parviflorum Small Yellow Lady's Slipper}

\section{A. Classification}

1. Family: Orchidaceae (Orchid Family). The Orchid Family is perhaps the largest family of vascular plants, with over 15,000 species worldwide (Cronquist 1988). Most of these species are in the tropics. Sometimes the genus Cypripedium is segregated from the orchid family and placed in the Cypripediaceae (Correll 1950, Weber and Wittmann 1992).

2. Genus: Cypripedium, the lady's slippers, is a genus of about 50 species native to North America and Eurasia (Correll 1950).

3. Species and Varicty: Yellow lady's slippers in Montana have traditionally been treated as Cypripedium calceolus L. var. parviflorum Salisb., as presented in Flora of the Pacific Northwest (Hitchcock and Cronquist 1976) and this name will be used throughout this report. However, the taxonomy of our plants is uncertain and changes in accepted names seem likely. Dr. Charles Sheviak, who is currently working with yellow lady's slippers, considers North American plants distinct from European C. calceolus at the species level (Sheviak 1992). Under this taxonomic treatment American plants are called $\mathrm{C}$. parviflorum Salisb.. It is uncertain what varieties are present in Montana. Correll (1950) considered $\mathrm{C}$. calceolus in North America to consist of one polymorphic variety, Cypripedium calceolus L. var. pubescens (Willd.) Correll, but his book includes a discussion of ecological "varieties" including a northern "var." parviflorum which is, like Montana plants, adapted to calcareous wetlands. Luer (1976) recognizes $\underline{C}$. calceolus var. parviflorum but does not show a western distribution for it, instead showing a northwestern Montana distribution for C. calceolus var. pubescens. Sheviak (1994) contends that $C$. parviflorum var. parviflorum is a southeastern woodland taxon. $\mathrm{He}$ thinks (Sheviak pers. commun.) that Montana yellow lady's slippers include $\underline{C}$.

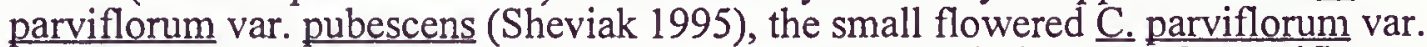
makasin (Sheviak 1993), and C. X columbianum, a hybrid between $\underline{C}$. parviflorum and $\underline{C}$. montanum (Sheviak 1992). Specimens from the KNF sent to Sheviak for identification have not been received back as of this writing. Montana specimens at the University of Montana (MONTU) and Montana State University (MONT) are also in need of annotation to variety. Resolution of the taxonomy of Montana yellow lady's slippers is important for considering state and global ranks as well as U.S. Forest Service status.

\section{B. Present legal or other formal status}

1. Federal

a. U.S. Fish and Wildlife Service: none

b. U.S. Forest Service: Sensitive in Region 1 (U.S. Forest Service 1994).

2. State: The Montana Natural Heritage Program ranks the variety G5Q and S2S3 (Heidel 1995). This signifies that it is demonstrably secure globally although there are taxonomic questions which need to be resolved, but is vulnerable to very vulnerable to extinction in Montana. 


\section{Description}

1. General nontechnical description: "This species of lady's slipper has leafy stems $15-40$ $\mathrm{cm}$ tall from a short rhizome. The elliptic leaves are $6-17 \mathrm{~cm}$ long, and sheath the stem. The foliage is lightly pubescent and usually glandular. The 1-2 flowers are subtended by an erect leafy bract, often longer than the inflorescence. The narrow sepals are up to $4 \mathrm{~cm}$ long, and wavy-margined or slightly twisted. One petal is strongly pouch-shaped and often purple-dotted. The other 2 petals are united into one that is similar to the sepals but slightly longer. The fruit is an elliptic capsule bearing many thousands of tiny seeds" (U.S. Forest Service 1995). Photographic slides of flowering plants are included in Appendix C.

2. Technical description: Plant terrestrial, sparsely pubescent, typically slender, up to 35 $\mathrm{cm}$ tall, from a short rhizome with fibrous roots. Leaves 3 , occasionally 4 or 5 , ovatelanceolate, plicate, bluish green, $5-15 \times 2-8 \mathrm{~cm}$ in 2 ranks. Inflorescence with 1 or 2 small, showy flowers. Floral bract foliaceous, $3-8 \times 1-3 \mathrm{~cm}$. Ovary subsessile, $15 \times 3$ $\mathrm{mm}$. Dorsal sepal ovate-lanceolate, undulate, from reddish to purplish-brown, $2-4$ X 1.5$2.5 \mathrm{~cm}$. Lateral sepals united often to the apex, similar to the dorsal sepal. Petals linearlanceolate, twisted, similar in color to the sepals, $3-5 \mathrm{~cm}$ X 5-8 $\mathrm{mm}$. Lip an ovoid pouch, clear deep yellow, the edges of the aperture rolled in, spotted inside with dark purple, 2$2.5 \times 1.2-2 \mathrm{~cm}$. Staminode bluntly triangular, deep yellow with purple sots, $8 \times 8 \mathrm{~mm}$. Capsule ellipsoid. (adapted from Luer 1975, for Cypripedium calceolus var. parviflorum; note: See discussion of species classification above; this technical description probably does not apply to Montana plants.)

3. Local field characters: As its taxonomy is treated here Cypripedium calceolus var. parviflorum is the only lady's slipper in Montana which has a yellow lip. When they are learned, the genus Cypripedium on the KNF can be recognized vegetatively or in fruit, but plants may be difficult to determine to the species level. Cypripedium montanum is often more robust than $\underline{C}$. calceolus var. parviflorum and usually has more flowers (or fruits) and broader leaves. The foliage and stem of $\mathrm{C}$. passerinum is more densely silky, glandular pubescent and the leaves are somewhat lighter colored.

\section{Geographical distribution}

1. Range of the species and variety: Depending on the taxonomic treatment (see above), Cypripedium calceolus is considered either a strictly Eurasian species (Sheviak 1992) or a circumborial species with varieties ranging across North America (Correll 1950, Luer 1975). In North America, the species (in the broad taxonomic sense) occurs as far north as the Yukon and Newfoundland and as far south as Arizona and Louisiana (Correll 1950, Luer 1975). The taxonomy and distribution of varieties remains controversial. Many authors (Cronquist et al. 1977, Hitchcock and Cronquist 1975, Welsh et al. 1987) consider $\mathrm{C}$. calceolus var. parviflorum to include plants with a northwestern distribution extending at least as far south as Utah, however, Luer (1975) maps its distribution only as far west as Wisconsin, giving a Montana distribution only for the transcontinental $\underline{C}$. calceolus var. pubescens. Dorn (1992) recognizes only C. calceolus var. pubescens in Wyoming. Charles Sheviak (pers. commun.) has tentatively recognized C. parviflorum var. pubescens and $\underline{C}$. parviflorum var. makasin in Montana, with the former having a transcontinental range and the latter occurring in Michigan, the Pacific Northwest and Western Canada. He contends $\underline{C}$. parviflorum var. parviflorum is endemic to the southeastern United States. 
2. Montana distribution: There are now at least 55 occurrences of Cypripedium calceolus var. parviflorum entered in the Biological Conservation Database (Figure 1 inset). These are all in the western half of the state in Flathead (11 occurrences), Gallatin (4), Granite (1), Judith Basin (1), Lake (8), Lewis and Clark (5), Lincoln (15), Missoula (3), Park (1), Stillwater (1), Sweet Grass (1), and Teton (4) counties (Figure 1 inset). Eleven of these occurrences, including all records from Gallatin, Granite, Park, Stillwater, and Sweet Grass counties, are historical, represented only by pre-1950 collections. The area of the Granite County occurrence has been surveyed and the population is believed to be extirpated (Heidel 1992). These numbers do not include possible 1995 discoveries outside the KNF.

\section{Occurrences on the Kootenai National Forest}

a. Current sites: There are now 15 populations of Cypripedium calceolus var. parviflorum known on the KNF with subpopulations on adjacent lands which are private or administered by the Army Corps of Engineers. Twelve of these populations are on the Fortine Ranger District in the Rocky Mountain Trench portion of the Forest and three are on the Libby. Ranger District near Libby Dam (Figure 1). Five of these occurrences were discovered for the first time in 1995, and one at Libby Dam (040) was previously known but had not been reported to MTNHP and had not been known to extend onto KNF land. Element Occurrence Records and topographic maps showing the precise locations of these populations are provided in Appendix A.

b. Historical sites: none

c. Unverified/undocumented reports: Four reports of unidentified Cypripedium species were found by Forest Service personnel (M. Lolly, pers. commun.) or myself to be the relatively common $\mathrm{C}$. montanum. These include plants at Alexander Creek (T31N R30W S24), Elk Creek (T26N R28W S14), Severn Gulch (T30N R30W S22), and in the drainage of Wolf Creek (T29N R28W S28), all on the Libby District. Another unidentified report (G. Heslink, pers. commun.) was surveyed on private land at the base of Yaak Mountain (T33N R33W S31) and may extend upstream onto KNF land. The plants were past flowering at the survey date but the presence of more than two fruits per stem and wide leaves suggest that they are Cypripedium montanum; however, the presence of Cypripedium calceolus var. parviflorum in this vicinity should not by ruled out because the bed of the small stream there is heavily laden with calcium.

d. Areas surveyed but species not located: The following areas were searched for sensitive Cypripedium species, but none were found. Especially significant is the absence of these orchids over large areas with calcareous soils, indicated by land types 323,324 and especially 325 (Kuennen and Gerhardt 1984), in creek and draw bottoms and adjacent to wetlands on the Fortine and Rexford Districts; many of these habitats seem appropriate for these orchids but are heavily impacted by cattle grazing. The following list is arranged by Ranger District and site names. The legal description is given to the precision of section. Searches were concentrated in the creek and draw bottoms and around lakeshores and wetlands. When land ownership is other than KNF it is noted. 
Fisher River Ranger District

Alexander Creek: T31N R29W S32

Buck Creek (Plum Creek Timber): T29N R29W S5

Cow Creek: T28N R28W S11

Doe Creek (Plum Creek Timber): T29N R29W S20

Peace Creek: T31N R29W S20, 21

Souse Creek: T31N R29W S29

\section{Fortine Ranger District}

Beaver Creek (State of Montana and KNF): T33N R26W S16, 21

Deep Creek: T35N R25W S20

Graves Creek: T30N R25W S33

Homes Lake: T35N R26W S34

Ivor Creek: T34N R26W S27

Jim Creek: T33N R26W S24

Lime Creek: T34N R26W S36, note: I also checked T33N R25W S5 and 6 in June and found no Cypripedium, but Jack Triepke, Fortine R. D. botanist, found a few stems of C. calceolus var. parviflorum in fruit in each section in August; the entire drainage has a high potential for sensitive orchids but is heavily impacted by cattle.

Lost Lake: T35N R27W S1, T35N R26W S6

Rock Lake: T35N R26W S6

Sink Creek: T34N R25W S14

Stewart Creek: T33N R25W S13, 14

Wigwam River: T37N R25W S14

\section{Libby Ranger District}

Doak Creek: T31N R30W S8, 18

Loon Lake: T33N R32W S24, 25

Tubb Gulch: T31N R30W S18, 19, 20

Rexford Ranger District

Melvin Draw: T36N R28W S23, 26

Pinkham Creek/Black Butte: T36N R28W S25, T36N R27W S30, 31

Teepee Lake: T35N R27W S21

\section{Three Rivers Ranger District}

Kilbrennon Creek: T33N R33W S29, 30, 31, 32

Little Lime Creek: T29W R29W S32

Lime Creek: T37N R29W S32

O'Brian Creek (unknown private): T32N R34W S12

\section{E. Habitat}

1. Associated vegetation: Compared to Cypripedium passerinum, discussed later in this report, $\mathrm{C}$. calceolus var. parviflorum grows in a slightly broader range of habitats in Montana. The typical habitat, however, is much the same, and at many sites, the two sensitive lady's slippers, and a third sensitive orchid, Orchis rotundifolia, grow together at the same site. Thus, known occurrences of any of these species should be considered potential habitat for the others. Typically, in Montana, C. calceolus var. parviflorum 
grows along ecotonal margins of spruce (Picea engelmannii, $\underline{\text { P. glauca, }}$, or hybrids) habitat types with wetland features such as fens, bogs, streamsides, lakeshores, and springs. The vegetation varies depending on landform, elevation, and geography. Some of the less typical habitats where the species grows in the state include Aspen stands, other coniferous forests such as Douglas fir (Pseudotsuga menziesii) habitat types, brushy river bottoms, willow stringers, and disturbed roadsides with other wet site plants.

On the Kootenai National Forest there is also a range of vegetation types which support Cypripedium calceolus var. parviflorum, but most populations are associated with spruce forest/wetland ecotones. Most sites key to the Picea/ Clintonia uniflora, Picea/Equisetum arvense (Pfister et al. 1977) or Picea/Cornus stolonifera (Hansen et al. 1995) habitat types. At two sites, however, the presence of spruce was not noted on field survey forms, but Douglas fir was present; these are at Glen Creek (054) and near the Confluence of the Kootenai and Fisher Rivers (051). The latter is in draw bottoms dominated by aspen (Populus tremuloides) and deciduous shrubs (slide 2 in Appendix C). At a third occurrence, Ant Flat (025), the habitat is also quite different, although the surrounding forest is dominated by spruce; here the orchids grow in willow (Salix bebbiana) thickets and in a moist "meadow" with shrubby cinquefoil (Potentilla fruticosa). The plants at Ant Flat are very small, perhaps due to low vigor resulting from high levels of competition in the relatively sunny, open habitat.

The typical ecotonal habitat of Cypripedium calceolus var. parviflorum on the KNF hosts a unique and characteristic assemblage of plants adapted to calcareous wetlands. Deciduous trees which sometimes occur at the sites include Betula papyrifera and Populus balsamifera. Deciduous shrubs often contribute greater canopy cover at the sites than trees; these include Alnus viridis, Betula glandulosa or Betula occidentalis, Cornus stolonifera, Lonicera involucrata and Rhamnus alnifolia. Graminoid cover, mostly by small sedges such as Carex interior, Carex cappilaris and Carex leptalea may be moderate to high. Cover by forbs is usually high; common associated forbs include Galium triflorum, Mitella nuda, Petasites sagitatus, Rubus pubescens, and other orchids like Habenaria dilatata and Habenaria saccata. Horsetails are also usually conspicuous and include Equisetum arvense, Equisetum hymale, and Equisetum scirpoides. Moss cover is usually very high in these habitats.

ECODATA plots were sampled at Brimstone Creek (026), Magnesia Creek (029) and in the Hidden Lake Area (027). This data is provided in Appendix B, and includes complete lists of vascular plant species in the plots and their aerial coverage. Additional associated plant species are listed in the general site description fields of the Element Occurrence Records in Appendix A. Photographic slides showing the vegetation at several sites are included in Appendix C.

2. Topography: Cypripedium calceolus var. parviflorum grows in glaciated valley or draw bottoms at relatively low elevations on the KNF. Elevations of the population sites range from 2,600 feet at Libby Dam (040) to 3,800 feet at Glen Creek (054) and Magnesia Creek (029). Populations are associated with high watertable features such as wetlands and moist draw bottoms. These are settings of stable ground water discharge, and $\underline{C}$. calceolus var. parviflorum is usually restricted to the discharge zone. The sites are usually level but at Libby Dam and Glen Creek the plants grow next to streams on moderate slopes. At the wettest sites the plants grow on hummocks, while in more mesic habitats they have a more scattered distribution across flats and in swales.

3. Soil relationships: Cypripedium calceolus var. parviflorum is adapted to cool, moist, 
calcareous soils. In a discussion of ecological "varieties" of C. calceolus in Correll (1950), "var." parviflorum is considered especially difficult to cultivate due to its strict requirements of soil $\mathrm{pH}$, moisture, and temperature. On the $\mathrm{KNF}, \mathrm{C}$. calceolus var. parviflorum is known to occur within seven landtypes (Kuennen and Gerhardt 1984); these are landtypes $105,108,321,323,324,325$, and 355 . The most vigorous populations (Brimstone Creek 026, Hidden Lake Area 027, and Magnesia Creek 029) are within landtype 325 , with soils classified as typic calciborolls with a high percentage of reprecipitated calcium carbonate; the parent material is alluvium, with the calcium derived from glacial till scoured from Precambrian Siyeh limestone. Landtypes 321, 323, and 324 have soils derived from calcareous glacial till. Where $C$. calceolus var. parviflorum occurs on the alluvial landtypes 105 and 108, the sites are adjacent to and downstream from landtype 323, and reprecipitated calcium is usually evident in the soil. One population site (Jumbo Lake .023) occurs within the landtype 355 mapping unit which has soils which are not noted as being calcareous, however, this is thought to be an artifact of the mapping precision because a highly calcareous horizon is noted on the Element Occurrence Record (Appendix A). In fact, it is likely that more precise mapping would result in many of the sites being reclassified as landtype 325, the type which most closely describes the soils where $\mathrm{C}$. calceolus var. parviflorum grows. Nearly all occurrences are in drainages, usually mapped as glacial till, which are downslope from or surrounded by the main body of the Helena formation as mapped by Harrison et al. (1992). This formation, which is differentiated from the traditional Siyeh formation, consists of dolomites and dolomitic siltites.

4. Climate factors: Cypripedium calceolus var. parviflorum has a broad distribution both north and south of Montana, and within the state it occurs both east and west of the Continental Divide with climate regimes ranging from humid to semi-arid. Its moisture requirements are generally met by a stable, cool, groundwater discharge which compensates for macroclimate differences. Data from the climatological station at Fortine (National Oceanic and Atmospheric Administration 1982) at 3,000 feet elevation characterize the climate where the taxon is concentrated on the Fortine District. From 1951 to 1980 the mean temperature normals range from $19.8^{\circ} \mathrm{F}$ in January to $63.8^{\circ} \mathrm{F}$ in July and the normal annual precipitation was 17.25 inches. The sites near Libby Dam are characterized by data from the closest station in Libby at 2,080 feet. Mean temperature normals ranged from $22.7^{\circ} \mathrm{F}$ in January to $66.7^{\circ} \mathrm{F}$ in July and normal annual precipitation was 18.66 inches.

\section{F. Population demography and biology}

1. Phenology: On the KNF, flowering is in late May to early July and fruit are produced in July through August. Cypripedium calceolus var. parviflorum is reported as flowering somewhat earlier than $\mathrm{C}$. passerinum (Lesica and Shelly 1991), but on the KNF where they grow together they were flowering concurrently in 1995. Flowers are needed for reliable identification, thus, occurrences found late in the season in fruit (e.g. Lime Creek $.055)$ need to be revisited earlier in the season to verify their identity.

2. Population size and condition: Evaluation of population numbers is difficult because there has not been consistent distinction between aerial stems, which may be clonal (ramets), and individual plants or clumps of stems, presumably reproduced by seeds (genets). A conservative approach is to consider the following numbers in terms of aerial stems; the number of genets in a population may be considerably less (see discussion of vegetative reproduction below). Estimated population numbers in Montana range from two to over 1,000 stems. Most populations in the state consist of fewer than 200 stems, and many have fewer than 50 . Some of the largest populations are found on the Lewis 
and Clark National Forest along the Rocky Mountain Front Range. A very large population with as many as 3,000 estimated stems was also reported from private land near Whitefish.

On the Kootenai National Forest, estimated population size ranges from less than 10 stems at Glen Creek (054) and Lime Creek (055), to perhaps more than 1,000 stems in several subpopulations across over 20 acres along Magnesia Creek (029). Relatively large, vigorous populations covering significant areas are also found at Brimstone Creek (026) and in the Hidden Lake Area (027). Evidence of population decline was found by 1995 census numbers, compared to numbers from 1989 and 1991, at Dickey Lake (001) and Therriault Creek (030), both sites which were impacted by highway construction in the last few years (see slides 6, 7, 16, and 17 in Appendix C). The Therriault Creek population is nearly extirpated and remains in grave danger as silt fills the remaining small area of habitat. Fewer stems were also seen in the Homes Lake Area (028) which has received light use by cattle. There is, however, possible evidence of population growth over the same period at Butler (013) and Brimstone (026) Creeks. Estimates of population numbers and area are given, as available, in the element occurrence data and size fields of the Element Occurrence Records in Appendix A.

3. Reproductive biology: The reproductive biology of orchids in general is characterized by complex floral morphologies and mechanisms adapted to cross pollination by insects, and by the production of tiny seeds, potentially in great numbers, which can be dispersed long distances but which are dependent upon fungi for seed germination and seedling development.

Most species of Cypripedium are thought to depend on cross-pollination for sexual reproduction (Bernhardt 1990). In an examination of living material which included $\underline{C}$. calceolus var. parviflorum, Catling (1983) found no evidence of self-pollination in the genus except for $\mathrm{C}$. passerinum. High levels of heterozygosity found in populations of $\mathrm{C}$. calceolus var. parviflorum and other varieties of the species are also consistent with an outcrossing breeding system (Case 1993). Flowers of the lady's slippers are thought to be adapted to pollination by a variety of insects, including beetles and flies (Correll 1950), but bees are probably the primary pollinators for the genus (Bernhardt 1990, Catling 1983).

Germination of terrestrial orchid seeds depends on penetration by fungal hyphae, and the plants grow underground as colorless mycorhizomes for a period of time before producing photosynthetic tissue (Wells 1981). Data from Europe (cited in Wells 1981) indicate that plants of Cypripedium calceolus are very slow to mature, producing their first leaves four years after germination and first flowering after about 16 years.

Cypripedium calceolus var. parviflorum reproduces both vegetatively, by rhizomes, and sexually, by seeds, although the relative degree of each method in a population is difficult to determine. Bernhardt (1990) speculates that large colonies of lady's slippers may be clonal and fail to produce fruit due to low rates of cross-pollination. Poor fruit production has been noted in many Montana populations of $\underline{C}$. calceolus. var.

parviflorum. On the KNF most population surveys have been conducted in June when the plants were flowering, however, fruits have been observed at a few sites at later dates (see the element occurrence data fields on the Element Occurrence Records in Appendix A). The presence of flowers is not necessarily an indication of reproductive success and numbers of aerial stems are not a true indication of population size or condition.

Vegetative reproduction allows a population to persist and spread locally, but alone does not supply genetic variation which allows the population to adapt or seeds for long distance migration. 
Species of Cypripedium, like many orchids, are known to hybridize. In British Columbia $\underline{C}$. calceolus ( $\underline{C}$. parviflorum) hybridizes with $\underline{C}$. montanum to make Cypripedium $X$ columbianum (Sheviak 1992). There is evidence of hybridization between C. calceolus var. parviflorum and C. montanum from several sites in Montana, notably on the Lewis and Clark National Forest along the Rocky Mountain Front Range. There, populations of yellow lady's slippers have plants with white and cream colored flowers. There is also evidence of hybridization between these two taxa at Libby Dam (040) and a report of plants with off colored flowers at Butler Creek (013) on the KNF (L. Kuennen, pers. commun.). Specimens from Libby Dam were sent to Dr. Charles Sheviak (New York State Museum) to determine if they are hybrids. Sheviak (1992) postulates that hybridization and introgression between $\underline{C}$. calceolus (C. parviflorum) and Cypripedium montanum may have played an important role in creating the variation seen in northwestern yellow lady's slippers today. Although $\underline{C}$. calceolus var. parviflorum and $\underline{C}$. passerinum grow together at several sites on the $\mathrm{KNF}$, no hybrids were seen; this may be partially due to the small size of the latter's lip which adapts it to smaller pollinators (Bernhardt 1990) and its capacity for self pollination (Catling 1983). However, a putative hybrid between these two taxa has been reported from the Rocky Mountain Front Range in Montana on the Lewis and Clark National Forest.

\section{G. Population ecology}

1. Competition: Cypripedium calceolus var. parviflorum usually grows in areas with very high plant cover and at some sites displays a degree of dominance in its habitat. Its rhizomatous habitat probably helps it to compete successfully with other plants, especially other forbs. However, plants were not found adjacent to populations in areas dominated by rhizomatous sedges (e.g. Carex utriculata, Carex vesicaria), suggesting it is not competitive with such species. At Ant Flat (025) Cypripedium calceolus var. parviflorum grows in an unusual "meadow" habitat with heavy competition from graminoids and shrubs and the plants are widely scattered and unusually small; part of this area may have been burned in 1992 (see Element Occurrence Record in Appendix A). Canopy cover also seems to effect reproductive success; plants growing in heavy shade are often vegetative and of low vigor. Studies on another species of lady's slipper, Cypripedium candidum, which grows in a rich fen in western New York, showed that large flowering genets were associated with higher levels of light than smaller vegetative genets (Falb and Leopold 1993).

2. Positive Interactions: The orchid family is characterized by strong mycotrophy (Cronquist 1988). Although seeds of Cypripedium calceolus var. parviflorum have been germinated under laboratory conditions without a fungal symbiont (e.g. De Pau and Remphrey 1993) it is unlikely that seeds germinate in nature before penetration by fungal hyphae (Wells 1981). The plants remain colorless underground, dependent on a fungus, for a some years before they produce their first photosynthetic leaf (Wells 1981). The fungal symbiont of orchids is usually a species of Rhizoctonia (Wells 1981), a genus of soil fungi which includes many plant pathogens (Agrios 1978).

3. Herbivory: Herbivory has not been noted on Element Occurrence Records from the KNF or elsewhere in Montana, although at one site "damage" by deer was noted. It is not known if cattle eat Cypripedium calceolus var. parviflorum but the species is absent from heavily grazed areas and little evidence of cattle was observed in the known population areas.

H. Land ownership: All of the known populations in the area of the KNF occur on Forest Service land, but at Libby Dam (040) most of the population is on Army Corps of 
Engineers land, near the Confluence of the Kootenai and Fisher Rivers (051) a subpopulation is on Plum Creek Timber Co. land, and at Magnesia Creek (029) the population extends onto private land. Additional occurrences are likely on private lands in creek bottoms which have not been surveyed.

\section{Assessment and management recommendations}

1. Threats to currently known populations: The major threats to Cypripedium calceolus var. parviflorum on the KNF are road building and cattle grazing, but logging may have indirect effects, and there is a potential for populations to be threatened by collection of plants by the general public. Any other activities which impede or reduce groundwater flow at its population sites are also threats.

Two populations, Dickey Lake (001) and Therriault Creek (030), have been impacted by the recent reconstruction of U. S. Highway 93 and remain at risk due to silt runoff and accumulation above the population areas (see slides 6, 7, 16, and 17 in Appendix C); the Therriault Creek population has been nearly extirpated and is likely to become so if protective measures are not taken. It is also likely that road construction has reduced population areas at Brimstone Creek (026) and Butler Creek (013) both of which are bisected by gravel roads. Damage from road construction at these sites, however, seems to be stabilized at this time. Populations of sensitive orchids on the KNF often occupy level topographic positions which are favored for road routes, especially stream crossings.

The threat from cattle grazing is speculative but persuasive, supported by inference on the $\mathrm{KNF}$ and the Custer National Forest. Seemingly suitable habitats which are grazed have few or no lady's slippers, and the areas which support the orchids have little or no evidence of cattle use. In the area of Homes Lake (028), where a low level of grazing was noted in 1991, the plants were confined to hummocks protected by brush (Chadde 1991). I revisited this population in 1995 and observed fewer plants than reported in 1991 and these had low vigor (slide 9, Appendix C), but I found little evidence of recent grazing. I searched the drainage of Lime Creek and found heavy grazing but no Cypripedium, however, later in the season Jack Triepke found a few stems in the area (occurrence 055), verifying that the habitat is appropriate for the orchids. Another sensitive orchid, Orchis rotundifolia, occurs in this drainage and was relocated in grazed habitat in 1995, but it is likely that the low growing and non-rhizomatous habit of this plant make it more tolerant of grazing. The fragile rhizomatous habit of $\underline{C}$. calceolus var. parviflorum probably makes the plants highly susceptible to trampling, and its succulent, upright foliage may be palatable to cattle. Heavy grazing is also likely to effect the hydrology of riparian zones. Most of the known populations on the KNF are within range allotments. On the Sheyenne District of the Custer National Forest all occurrences of $\underline{C}$. calceolus var. parviflorum are within grazing allotments, but three are restricted to exclosures and the others are in very low numbers or otherwise difficult for cattle to access (North Dakota Parks and Recreation Department 1990).

Logging and road building adjacent to population areas may threaten the plants by making the sites more accessible to cattle and by affecting the hydrology of the sites. The riparian areas where Cypripedium calceolus grows on the KNF are generally excluded from logging by management guidelines. Logging of surrounding forests may have effects on the hydrology of the population sites, but these are difficult to predict. Changes to the hydrology can be expected to affect the populations and potential habitat. Lady's slippers are the among the most beautiful flowers known and are coveted as cut flowers and for propagation as ornamentals; the rhizomes were historically in high demand for their reputed medicinal properties (Correll 1950), and continue to be offered 
by some dealers of native medicinal herbs (Fuller 1991). Historical accounts suggest that species of Cypripedium were once far more plentiful than they are today, and their downfall has been partially attributed to over-collection (Bernhardt 1990). Although collecting was not evident at any of the sites visited in 1995, probably because the wet sites are difficult to access and little visited, collection has been noted at other Montana sites and should be a concern on the KNF. A friend admitted they usually pick a bouquet of yellow lady's slippers every June; they did not realize the plants are rare and may be threatened by this activity. Digging of plants is especially detrimental considering the long time it takes for them to mature. The strict habitat and symbiotic requirements of $\mathrm{C}$. calceolus var. parviflorum make it difficult or impossible to propagate, contrary to directions given in the older literature (e. g. Correll 1950). In a survey of catalogs offering native medicinal plants, $15 \%$ offered rhizomes of Cypripedium, most often $\underline{\mathrm{C}}$. calceolus (Fuller 1990). The resurgence of interest in herbal medicines may increase collection and significantly threaten populations of the species in the future. Collection is a special concern at sites, such as Dickey Lake (001) and Libby Dam (040), which are close to popular recreation areas. The collecting pressures on this species among hobby gardeners and commercial collectors are under review for treating the EOR locations as sensitive, whereupon precise location information is not distributed by MTNHP except as needed by managing agencies and researchers. Input from U.S. Forest Service personnel is solicited.

2. Management practices and response: Often populations have been protected from direct effects of logging by riparian guidelines or lack of marketable timber in the riparian corridor. At Butler Creek (013) and Confluence of the Kootenai and Fisher Rivers (051) populations have been disturbed by logging skid trails where they cross the draws, but at both sites plants have begun to recolonize the disturbances.

Most of the population areas on the Fortine District are within grazing allotments and the sites which show some degree of use by cattle (Homes Lake Area .028, and Lime Creek .055) support relatively few plants, especially the heavily grazed Lime Creek site. Studies on another species of lady's slipper, Cypripedium candidum, which occupies a rich fen in western New York, show that the invasion and growth of this species began soon after cessation of grazing at the site (Falb and Leopold 1993). An exclosure is recommended at the Lime Creek (055) site to determine the effects of grazing on $\mathrm{C}$. calceolus var. parviflorum; this will need to be set up as a long term project due to the slow development of the orchids from seed.

Management Summary: Although a few new populations of Cypripedium calceolus var. parviflorum were found on the KNF in 1995, current Montana Natural Heritage Program state rank of S2S3 and Forest Service Sensitive status remain appropriate. Most of the populations on the KNF and in Montana are small and reproductive success may be limited. Many occurrences and much of the Montana range of the taxon is based only on historical collections. Threats to populations are many and are likely to increase as human populations and rural residences increase.

Revisions in the taxonomy of yellow lady's slippers in Montana will require a reappraisal of state and global ranks. Representative collections are needed to determine which varieties of yellow lady's slippers occur in Montana, however, over collection is a threat to populations. Guidelines for collecting native plants have been established by the Montana Native Plant Society (1993). Widespread and long standing collecting pressures on lady's slipper orchids (Bernhardt 1990, Fuller 1991) are basis for extra caution in collecting these rare plants. Collecting should be limited to taking few above ground stems from large populations and all specimens should be deposited in established 
herbaria. A relatively large number of specimens of yellow lady's slippers are housed at the University of Montana (MONTU), and annotation of these to variety is needed before further collection priorities are set.

The priority for conservation of yellow lady's slippers on the KNF should be to insure that all high quality occurrences on the KNF are preserved at their current population levels. This may require perpetuation of existing land uses patterns in which cattle are kept out of the population areas. Currently most large populations are in areas with pristine habitat, but this could change if grazing allotment use patterns change. Especially at risk are the Brimstone Creek (026), Homes Lake Area (028) and Magnesia Creek (029) populations, which are closest to drainages which are currently heavily grazed. At some sites, such as the Homes Lake Area (028), strategically falling a few trees across the draw may be a simple way to restrict cattle access and improve site conditions. Several unique wetlands on the KNF support populations of three Sensitive orchids, Cypripedium

calceolus var. parviflorum, $C$. passerinum, and Orchis rotundifolia, and these sites should be considered for designation as Research Natural Areas or Botanical Special Interest Areas. Such areas include Brimstone Creek (026), the Jumbo Lake Basin (023 and 027), Magnesia Creek (029) and Laughing Water Creek (049). These sites, along with occurrences on the Flathead and Lewis and Clark National Forests, represent the largest populations of $\underline{\underline{C}}$ calceolus var. parviflorum on public lands in Montana. 


\author{
Cypripedium passerinum \\ Sparrow's Egg Lady's Slipper
}

\title{
A. Classification
}

1. Family: Orchidaceae (Orchid Family). The Orchid Family is perhaps the largest family of vascular plants, with over 15,000 species worldwide (Cronquist 1988). Most of these species are in the tropics. Sometimes the genus Cypripedium is segregated from the orchid family and placed in the Cypripediaceae (Weber and Wittmann 1992).

2. Genus: Cypripedium, the lady's slippers, is a genus of about 50 species native to North America and Eurasia (Correll 1950).

3. Species: Cypripedium passerinum Richards

B. Present legal or other formal status

1. Federal status

a. U.S. Fish and Wildlife Service: none

b. U.S. Forest Service: Sensitive in Region 1 (U.S. Forest Service 1994).

2. State: The Montana Natural Heritage Program ranks the species G4G5 and S2 (Heidel 1995). This signifies that it is apparently to demonstrably secure throughout it's global range but is imperilled because of rarity in Montana.

C. Description

1. General nontechnical description: Sparrow's egg lady's slipper has leafy stems up to 35 $\mathrm{cm}$ high from slender, creeping rhizomes. The 3-5 broadly lance-shaped leaves are up to $35 \mathrm{~cm}$ long and clasp the stem. The herbage is covered with long, soft hairs and is usually somewhat sticky. The one or two flowers are subtended by a leafy bract which is longer than the inflorescence. The sepals are green and 10-16 mm long, the upper one longer than the lower two. The petals are white, the lower one is pouchlike with purple spots on the inside, and the other two resemble the sepals but are shorter. The erect capsule is ovoid and bears thousands of tiny seeds (U.S. Forest Service 1995). Slides of flowering plants photographed on the KNF are included in Appendix C.

2. Technical description: Plant terrestrial, pubescent, up to $35 \mathrm{~cm}$ tall from a short rhizome with fibrous roots. Leaves 3-5, ovate-lanceolate, plicate, light green, 5-15 X 1.5$5 \mathrm{~cm}$, sheathing the stem. Inflorescence with a usually solitary, inconspicuous flower. Floral bract foliaceous, ovate-lanceolate, $3-5 \times 1-2 \mathrm{~cm}$, sheathing the ovary. Ovary subsessile, stout, pubescent, $17 \times 7 \mathrm{~mm}$. Dorsal sepal suborbicular, concave, yellow green, $1.5-2 \times 1-1.5 \mathrm{~cm}$. Lateral sepals united nearly to apex and concave behind the lip, or sometimes free; similar to the dorsal sepal. Petals linear-oblong, spreading, flat, white, 12-20 X 3-4 mm. Lip an obovoid sac, the margins of the orifice folded in, white, suffused with pink near the base, minutely spotted with purple at the orifice and on the inside, $12-20 \times 8-13 \mathrm{~mm}$. Staminode ovate, white with yellow apex and spotted with purple, 6 X $5 \mathrm{~mm}$. Capsule ellipsoid, 1.5 X $2.5 \mathrm{~cm}$. (Luer 1975)

3. Local field characters: Unlike other lady's slippers on the KNF, Cypripedium passerinum has inconspicuous flowers which are whiteish green and do not have showy 
twisted petals. When they are learned, species of Cypripedium on the KNF can be recognized vegetatively or in fruit, but may be difficult to determine to the species level. Cypripedium montanum is often more robust, with wider leaves than $\mathrm{C}$. passerinum or $\mathrm{C}$. calceolus var. parviflorum and usually has more flowers (or fruits) per stem, often more than two. On the KNF Cypripedium passerinum usually has lighter colored leaves, is more densely silky pubescent, and is more strictly single flowered than $\mathrm{C}$. calceolus var. parviflorum.

\section{Geographical distribution}

1. Range: Northern North America, from Alaska to Quebec south to southeastern British Columbia, northern Montana, and Lake Superior (Hitchcock and Cronquist 1973). Cypripedium passerinum is one of the few orchids which grows above the Arctic Circle (Luer 1975).

2. Montana distribution: Cypripedium passerinum has a peripheral distribution in northwestern Montana, the only place where it grows south of the Canadian border (Luer 1975). There are now 27 occurrences in the state entered in the Biological Conservation Database (Figure 2 inset). These are in Flathead (8 occurrences), Lake (4), Lewis and Clark (3), Lincoln (5), Pondera (2), Powell (3), and Teton (2) counties. One of these occurrences, at Columbia Falls, is historical, represented only by an 1894 collection. These numbers do not include possible 1995 discoveries outside the KNF.

\section{Occurrences on the Kootenai National Forest}

a. Current sites: Cypripedium passerinum was first found on the KNF in 1992 (Hoitsma 1992) and is now known from six sites, all on the Fortine Ranger District (Figure 2). Two of these occurrences, Brimstone Creek (025) and Magnesia Fen (026), were new discoveries in 1995. Element Occurrence Records and topographic maps showing the precise locations of these populations are provided in Appendix A.

b. Historical sites: none

c. Unverified/undocumented sites: none

d. Areas surveyed but species not located: See listing under this heading for Cypripedium calceolus var. parviflorum.

\section{E. Habitat}

1. Associated vegetation: In Montana, Cypripedium passerinum is nearly always associated with spruce habitat types, usually on edges and ecotones with wetland features such as fens, swamps, deciduous riparian thickets, lakesides, and springs. On the KNF, the dominant tree species may be Picea engelmannii, $\underline{P}$ glauca, or hybrids, and habitats include the Picea/ Clintonia uniflora, Picea/Equisetum arvense (Pfister et al. 1977) and Picea/Cornus stolonifera (Hanson et al. 1995) types. Deciduous tree species at some sites include Betula papvrifera and Populus balsamifera. Common shrubs, which may contribute as much or more canopy cover than the dominant trees in these habitats, include Alnus viridis, Betula occidentalis or Betula glandulosa, Cornus stolonifera, Lonicera involucrata, and Rhamnus alnifolia. The sites with Cypripedium passerinum on the KNF have high coverage by a diversity of wet site forbs and the conspicuous presence of other orchids. At or nearby five of the six sites, two other sensitive orchids, Cypripedium calceolus var parviflorum and Orchis rotundifolia also occur. Thus, known 
sites for any of these sensitive orchids should be considered potential habitat for the others. Other common associated forbs are Clintonia uniflora, Cornus canadensis, Petasites sagitata, Rubus pubescens, and species of Viola. Graminoid cover is predominantly by small sedges such as Carex capillaris, $C$. disperma, and $C$. leptalea. The most common associated ferns are horsetails (Equisetum arvense, E. fluviatale, $E$. hymale, and E. scirpoides). Ground cover by mosses in these habitats is usually very high.

ECODATA plots were sampled at two sites with Cypriedium passerinum, at Brimstone Creek (025) and at Rattlebone Lake (020). This data is provided in Appendix B, and includes complete lists of vascular plant species in the plots and their aerial coverage. Additional associated plant species are listed in the general site description fields of the Element Occurrence Records in Appendix A. Photographic slides of the vegetation at three sites are provided in Appendix C.

2. Topography: On the KNF, all occurrences of Cypripedium passerinum are at relatively low elevations in glaciated valley bottoms, along low gradient streams or lakeshores in the Rocky Mountain Trench. Elevations range from 3,280 to 3,800 feet. The sites are all nearly level and have various aspects. At wet sites the plants grow on hummocks above the water table.

3. Soil relationships: Correll (1950) states that the species "grows in both circumneutral limestone gravels and moderately acid coniferous humus." In Montana, a calcareous parent material is often reported, and on the KNF most of the sites have soils with a high content of reprecipitated calcium. Four of the six known occurrences are on landtype 325 (Kuennen and Gerhardt 1984) with soils classified as typic calciborolls with a high percentage of reprecipitated calcium carbonate; the parent material is alluvium, with the calcium derived from glacial till scoured from Precambrian Siyeh limestone. At Rattlebone Lake (020) the landtype is 105, indicating lacustrine soils, with the surrounding drainage classified as type 355 with associated non-calcareous soils. The absence of Cypripedium calceolus var. parviflorum at this site is unique for occurrences on the KNF, thus $\mathrm{C}$. passerinum may be adapted to a wider range of soil $\mathrm{pH}$. The soils are subirrigated and moist. The species reaches its southernmost limits in Montana and extends north above the Arctic Circle; it is adapted to cool soils.

4. Climate factors: Cypripedium passerinum is adapted to growing in cold climates with short growing seasons, its distribution extending above the Arctic Circle. Data from the climatological station at Fortine (National Oceanic and Atmospheric Administration 1982) at 3,000 feet elevation characterizes the climate where the species grows on the KNF. From 1951 to 1980 the mean temperature normals ranged from $19.8^{\circ} \mathrm{F}$ in January to $63.8^{\circ}$ in July and the normal annual precipitation was 17.25 inches. The Rocky Mountain Front Range in Montana, where C. passerinum grows in greater numbers, has a colder climate and shorter growing season than the Rocky Mountain Trench where it grows on the KNF. Climate may be a factor in the low numbers of this species found on the KNF.

\section{F. Population demography and biology}

1. Phenology: The species flowers in June and produces fruit in late June to July. It is reported as flowering somewhat later than Cypripedium calceolus var. parviflorum (Lesica and Shelly 1991) but at sites hosting both species on the KNF they were flowering concurrently in 1995. 
2. Population demography and condition: Evaluation of population numbers is difficult because there has not been consistent distinction between aerial stems, which may be clonal (ramets), and individual plants, or clumps of stems, presumably reproduced by seeds (genets). A conservative approach is to consider the following numbers in terms of aerial stems; the number of genets in a population may be considerably less (see discussion of vegetative reproduction below). Throughout Montana, reported population numbers range from 2 to 1,200 aerial stems and areal coverage of the populations ranges from a few square feet up to 15 acres. Relatively large populations are reported from the Rocky Mountain Front, Glacier Park, and the Bob Marshall Wilderness. In contrast, Kootenai National Forest populations are extremely small. The highest number seen (64 "plants") was in 1993 at Laughing Water Creek. Hoitsma (1992) first found Cypripedium passerinum on the Kootenai National Forest and observed between 30 and 50 "plants" in each of three populations. In attempts to relocate two of these occurrences in 1995, I found only a few aerial stems at each site, and was unable to relocate all subpopulations. Also in 1995, Tobias Spribille observed only 15 "plants" at a newly discovered site for the species at Magnesia Creek, and I found just one clump with 3 stems at Brimstone Creek. Census numbers in 1995 may indicate population declines of C. passerinum on the Kootenai National Forest. None of the populations on the Kootenai cover more than one acre. Estimates of population numbers and area are given, as available, for all populations on the KNF in the element occurrence data and size fields of the Element Occurrence Records in Appendix A.

3. Reproductive biology: The reproductive biology of orchids in general is characterized by complex floral morphologies and mechanisms adapted to cross pollination by insects, and by the production of tiny seeds, potentially in great numbers, which can be dispersed long distances but which are dependent upon fungi for seed germination and seedling development.

Unlike most orchids and other species of Cypripedium, $\underline{C}$. passerinum has been shown to be capable of self pollination (Catling 1983). Tobias Spribille pointed out flowers of $\underline{C}$. passerinum at Laughing Water Creek (024) with ovaries beginning to expand before the flower had apparently opened, possible evidence of self pollination or agamospermy (vegetative production of seeds without fertilization), and I observed this condition at other sites on the KNF. Bernhardt (1990) states that the small lip size of C. passerinum makes it dependent on small bees for pollination, but Shelly (1980) observed no pollinator visitation to plants on the Flathead and Lewis and Clark National Forests, again suggesting self pollination. Self pollination, like vegetative reproduction, restricts gene flow leading to adaptation and evolution (Catling 1983), but may be important for the perpetuation of small isolated populations like those of $\mathrm{C}$. passerinum on the KNF. The

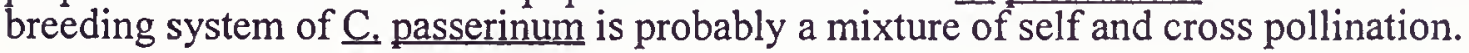

Germination of terrestrial orchid seeds depends on penetration by fungal hyphae, and the plants grow underground as colorless mycorhizomes for a period of time before producing photosynthetic tissue (Wells 1981).

Cypripedium passerinum can also reproduce vegetatively by rhizomes. These have been described as slender and creeping (Correll 1950) or as short (Luer 1975). The distance of potential spread by rhizomes remains unclear; plants which I observed on the KNF in 1995 grew in small compact clumps with just a few stems. Vegetative reproduction allows a population to persist and spread locally, but does not alone supply genetic variation which allows the population to adapt or seeds for long distance migration. 
Some species of Cypripedium are known to hybridize, for example $\underline{C}$. calceolus var.

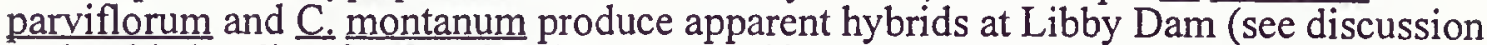
under this heading for $\underline{C}$. calceolus var. parviflorum). Although $\underline{C}$. calceolus var. parviflorum and $\mathrm{C}$. passerinum grow together at several sites on the KNF, no hybrids were seen; this may be partially due to the small size of the latter's lip which adapts it to smaller pollinators (Bernhardt 1990) and its capacity for self pollination (Catling 1983). A putative hybrid between these two taxa has been reported from the Rocky Mountain Front Range in Montana on the Lewis and Clark National Forest.

\section{G. Population ecology}

1. Competition: The sites where Cypripedium passerinum are found on the KNF usually have high vegetative cover but the sensitive plant is very scarce, suggesting that it may have poor competitive ability. The habitats are usually shared with $\underline{C}$. calceolus var. parviflorum which is always more abundant. The two species of lady's slippers occupy similar microhabitats but were not seen growing in close association, thus $\underline{C}$. calceolus var. parviflorum may be a superior competitor, to the exclusion of $\underline{\mathrm{C}}$. passerinum. Flowers were observed on plants growing in deep shade.

2. Positive Interactions: The orchid family is characterized by strong mycotrophy (Cronquist 1988). Although seeds of some species of Cypripedium (De Pau and Remphry 1993) have been germinated under laboratory conditions without a fungal symbiont, it is unlikely that seeds germinate in nature before penetration by fungal hyphae (Wells 1981). The plants remain colorless underground, dependent on a fungus, for a some years before they produce their first photosynthetic leaf (Wells 1981). The fungal symbiont of orchids is usually a species of Rhizoctonia (Wells 1981), a genus of soil fungi which includes many plant pathogens (Agrios 1978).

3. Herbivory: On the KNF in past years, light herbivory was noted at Rattlebone Lake (020) and browsing by game was noted at Laughing Water Creek (024). At Brimstone Creek (025), the single clump of Cypripedium passerinum found was growing under brush, a possible indication of vulnerability to herbivores. Severe grazing and trampling by cattle was noted at one site on the Lewis and Clark National Forest along the Rocky Mountain Front Range (Shelly 1988).

H. Land ownership: All occurrences are on KNF land on the Fortine District except Jumbo Lake (022) which is on state land but possibly extends onto the KNF Fortine District.

\section{Assessment and management recommendations}

1. Threats to currently known populations: Potential threats to Cypripedium passerinum are essentially the same as for Cypripedium calceolus var. parviflorum; see this heading for that species for a more complete discussion. These threats include grazing, road building, logging, and plant collecting. There are more reports of herbivory to Cypripedium passerinum than to Cypripedium calceolus var. parviflorum, a possible indication that it is more palatable and thus more susceptible to grazing. Its lower numbers on the KNF could be a reflection of extreme susceptibility to grazing and browsing by game, although there is no direct evidence of this. Its extreme rarity on the KNF make it especially vulnerable to extirpation caused not only by human caused disturbances but also due to natural population fluctuations, disease, and herbivory. The flowers of Cypripedium passerinum are quite inconspicuous and not showy, thus collection by people for cut flowers and propagation as ornamentals may be less of a threat to this species. 
2. Management practices and response: One population of Cypripedium passerinum in the Rocky Mountain Front Range on the Lewis and Clark National Forest was monitored before and after cattle grazed the area in 1988; of 160 stems observed on July 11 only 52 live stems were relocated on August 4 and others were bitten off or trampled (Shelly 1988).

3. Management summary: Although two new populations of Cypripedium passerinum were discovered in 1995, current Montana Natural Heritage Program state rank of S2 and Forest Service Sensitive status remain appropriate. All populations of $\underline{C}$. passerinum seen on the KNF in 1995 were extremely small and the species is highly vulnerable on the Forest. It is not known if the small population numbers are due to extreme susceptibility to grazing by cattle or browsing by game, or to climatic conditions, or to other causes.

Since Cypripedium passerinum almost always grows on the KNF with two other Sensitive orchids, $\underline{C}$. calceolus var. parviflorum and Orchis rotundifolia, preservation of wetlands which host all three species should be a priority for conservation management of the species. Sites with all three orchids are located at Brimstone Creek (025), the Jumbo Lake Basin (021, 022), Laughing Water Creek (024), and Magnesia Fen (026). Although habitat at these sites is currently in near pristine condition, this could change with changes in grazing allotment usage patterns. Cattle should be kept out of these areas. Designation as Research Natural Areas or Botanical Special Interest Areas may be appropriate. 


\section{Discussion}

In addition to their intrinsic value as elements of biodiversity, the Sensitive lady's slipper orchids on the KNF have significant aesthetic and commercial value, and their preservation should be an important conservation priority. Cypripedium calceolus var. parviflorum, in particular, has potentially enormous commercial value as an ornamental and pharmaceutical. Commercial use of this orchid will depend on scientific advances in cultivation from seed, a subject which is receiving considerable attention (e.g. De Pau and Remphrey 1993). The potential high demand for these rare plants is basis for special data security precautions and public education. Maintenance of genetic diversity necessary for the species to persist and evolve, as well as for commercial germplasm, will depend on prudent habitat conservation and protection of populations from exploitation.

As human population pressures continue to grow, remote occurrences of sensitive orchids on public land, like those on the KNF, will become more important to the perpetuation and evolution of their species. Much of the bottomland habitat which is potential habitat for sensitive orchids in the Rocky Mountain Trench near Fortine is on private lands subject to subdivision and increased residential use. At the same time, use of grazing allotments and recreation on public lands is likely to increase.

The most significant current threat to populations of the two sensitive Cypripedium species on the KNF is probably cattle grazing. Large populations of sensitive orchids seem to be restricted to areas protected by chance from cattle by windfall, heavy brush, and/or swampy soils. Historical and current allotment usage may also be a factor in the distribution of these species. All of the known populations of orchids are within open range allotments and are potentially threatened by changes in current grazing patterns. Populations may be opened up to grazing by adjacent logging and road building. Preservation of large populations of lady's slippers on the KNF will probably require that cattle be kept out of the population areas.

Few of the populations are given administrative protection and most lie in management areas designated as suitable timberland (U.S. Forest Service 1987); two exceptions are Brimstone Creek and Laughing Water Creek which lie just on the downstream edge of designated old growth. Designation of the Jumbo Lake Basin as a Botanical Special Interest Area or Research Natural Area has been suggested (Chadde 1989) and similar designation may be appropriate for significant orchid populations at Brimstone, Laughing Water, and Magnesia Creeks. All three of the sensitive orchids known on the KNF, Cypripedium calceolus var. parviflorum, $\underline{C}$. passerinum, and Orchis rotundifolia, are present at each of these sites, with one or more in significant numbers, and these areas have unique soils, geology, and floristic assemblages. Further surveys of these areas are recommended before conservation area boundaries are established, especially in the Jumbo Lake Basin where location discrepancies remain.

Clustered lady's slipper, Cypripedium fasciculatum, has still not been found on the KNF. Throughout its range, $C$. fasciculatum is found in a variety of habitats (Elliman and Dalton 1995), including Thuja plicata and Pseudotsuga menziesii habitat types which are common on the KNF. In 1995, I spent only a small amount of time looking for this species in the drainage of Big Beaver Creek on the Cabinet Ranger District. The habitat on the lower south facing slopes of this drainage and other east-west oriented drainages on the Cabinet District is similar to where the species is known not far south on the Lolo National Forest near St. Regis. On the Lolo, Cypripedium fasciculatum grows in Douglas fir/ninebark (Pseudotsuga menziesii/Physocarpus malvaceous) communities. In northwestern Montana, unlike more arid parts of the state, these communities occur on southerly aspects (Pfister et al. 1977). The rare lady's slipper grows in $\mathrm{cool}$, shaded microsites with little ground cover, on these relatively warm, open slopes. It thus seems, at this apparent northernmost extent of its range at this longitude, to require the best of all conditions. In 1995, an extremely cool, wet growing season, flowers were scarce and often 
aborted, a further indication that the species may be better adapted to a dryer, warmer, more southerly climate. Never the less, there remains potential for the species on the KNF, efforts to locate it should continue, and it should remain a search target for routine project clearances. Prior to 1991, just four years ago, Cypripedium fasciculatum was not known from the Lolo National Forest, but now it is known there in greater concentration than anywhere else in the state (Elliman and Dalton 1995). Kootenai National Forest botanists, especially those on the Cabinet District, are encouraged to visit the sites on the Lolo; Element Occurrence Records for two relatively easy sites to relocate are included at the end of Appendix A. Photographic slides of flowering plants of $\underline{C}$ fasciculatum are included in Appendix $\mathrm{C}$.

At present, the Kootenai National Forest, especially the Fortine District, hosts a relatively high density of Sensitive orchid occurrences, but these are restricted to small areas of specialized habitat. Many sites host three Sensitive orchids (Cypripedium calceolus var. parviflorum, $C$. passerinum, and Amerorchis rotundifolia), some with large numbers in pristine habitat settings. They include some of the largest known populations of Cypripedium calceolus var.parviflorum in the state, and populations of both species are geographically significant. But these populations may be threatened in the future by changing, likely increasing, pressures, including the direct and indirect effects of road building, cattle grazing, logging, and collection. Protecting these significant occurrences and unique habitats from these complex and interrelated threats will require a carefully planned conservation strategy. 


\section{Literature Cited}

Agrios, G. N. 1978. Plant pathology, second edition. Academic Press, New York, NY. 703 pp.

Bernhardt, P. 1990. Wily violets and underground orchids, revelations of a botanist. Random House, New York, NY.

Case, M. A. 1993. High levels of allozyme variation within Cypripedium calceolus (Orchidaceae) and low levels of divergence among its varieties. Systematic Botany 18(4): 663-677.

Catling, P. M. 1983. Autogamy in eastern Canadian Orchidaceae: a review of current knowledge and some new observations. Naturaliste Canada 110: 37-53.

Chadde, S. 1989. Survey of plants of limited distribution, Kootenai National Forest. Unpublished report, $82 \mathrm{pp}$.

1991. Sensitive Plant Survey, Pinkham Analysis Area, Fortine and Rexford Ranger Districts, Kootenai National Forest. Unpublished report, 26 pp. plus appendices.

Correll, D. S. 1950. Native Orchids of North America north of Mexico. Stanford University Press, Stanford, CA.

Cronquist, A. 1988. The evolution and classification of flowering plants. The New York Botanical Garden, Bronx, NY. 555 pp.

Cronquist, A., A. H. Holmgren, N. H. Holmgren, J. L. Reveal, and P. K. Holmgren. 1977. Intermountain flora; vascular plants of the intermountain west, volume six, the monocotyledons. Columbia University Press, New York, NY.

De Pau, M. A. and W. R. Remphrey. 1993. In vitro germination of three Cypripedium species in relation to time of seed collection, media, and cold treatment. Canadian Journal of Botany 71: 879-885.

Elliman, T. and A. Dalton. 1995. Cypripedium fasciculatum Kellogg ex Watson in Montana. North American Native Orchid Journal 1: 59-72.

Falb, D. L. and D. D. J. Leopold. 1993. Population dynamics of Cypripedium candidum Muhl. ex Willd., small white lady's slipper, in a western New York fen. Natural Areas Journal 13(2): 76-86.

Fuller, D. O. 1991. Medicine from the wild; an overview of the U.S. native medicinal plant trade and its conservation implications. World Wildlife Fund, Washington, DC.

Hansen, P. L., R. D. Pfister, K. Boggs, B. J. Cook, J. Joy, and D. K. Hinckley. 1995. Classification and management of Montana's riparian and wetland sites. Montana Forest and Conservation Experiment Station, School of Forestry, The University of Montana, Missoula, MT. $646 \mathrm{pp}$.

Harrison, J. E., E. R. Cressman, and J. W. Whipple. 1992. Geologic and structure maps of the Kalispell $1^{\circ} \times 2^{\circ}$ quadrangle, Montana, and Alberta and British Columbia. Miscellaneous Investigations Series, U.S. Dept. of Interior, U.S. Geological Survey.

Heidel, B. L. 1992. Survey of Cypripedium calceolus, U.S.D.I Bureau of Land Management, 
Butte District, Garnet Resource Area, Montana. Montana Natural Heritage Program, Helena MT. 10 pp.

- 1995. Montana plant species of special concern. Montana Natural Heritage Program, Helena, MT. Unpublished list.

Hoitsma, T. 1992. Sensitive Plant Survey, Fortine Ranger District, Kootenai National Forest. Unpublished report, $65 \mathrm{pp}$ plus appendices.

Kuennen, L. J., and M. N. Gerhardt. 1984. Kootenai National Forest Area Land System Inventory. U.S. Dept. of Agriculture, Forest Service, Kootenai National Forest, Libby, Montana. 416 pp. plus 116 inventory sheets.

Lesica, P. and J. S. Shelly. 1991. Sensitive, threatened, and endangered vascular plants of Montana. Montana Natural Heritage Program, Occasional Publication No. 1. Helena, MT. 88 pp.

Luer, C. A. 1975. The native orchids of the United States and Canada excluding Florida. The New York Botanical Garden, Bronx, NY.

Montana Native Plant Society. 1993. Guidelines for collecting native plants. Bozeman, MT.

National Oceanic and Atmospheric Administration. 1982. Monthly normals of temperature, precipitation, and heating and cooling degree days, 1951-80. National Climatic Data Center, Ashville, NC.

North Dakota Parks and Recreation Department. 1990. Inventory of rare plant species in the Sheyenne National Grasslands, Ransom and Richland Counties, North Dakota. Natural Heritage Inventory, Bismark ND.

Pfister, R. D., B. L. Kovalchik, S. F. Arno, and R. C. Presby. 1977. Forest habitat types of Montana. Intermountain Forest and Range Experiment Station, U. S. D. A. Forest Service, Ogden, UT.

Shelly, J. S. 1988. Status review of Cypripedium passerinum; U.S. Forest Service Region 1, Flathead and Lewis \& Clark National Forests, Montana. Montana Natural Heritage Program, Helena, MT. $52 \mathrm{pp}$.

Sheviak, C. J. 1992. Natural Hybridization between Cypripedium montanum and its yellowlipped relatives. American Orchid Society Bulletin 81: 546-559.

Sheviak, C. J. 1993. Cypripedium parviflorum Salisb. var. makasin (Farwell) Sheviak. American Orchid Society Bulletin 62(4):403.

Sheviak, C. J. 1994. Cypripedium parviflorum Salisb. I: The small-flowered varieties. American Orchid Society Bulletin 63:664-669.

Sheviak, C. J. 1995. Cypripedium parviflorum Salisb. Part 2: The large-flowered plants and patterns of variation. American Orchid Society Bulletin 64:606-612.

U. S. Forest Service. 1987. Forest Plan. Kootenai National Forest, Libby, MT. 
. 1992. Ecosystem inventory and analysis guide.

. 1994. Update of Northern Region sensitive plant list. Unpublished list. Missoula, MT. 19 pp.

. 1995. Kootenai National Forest sensitive plant field guide. Northern Region, Kootenai National Forest. Libby, MT.

Weber, W. A. and R. C. Wittmann. 1992. Catalog of the Colorado flora: a biodiversity baseline. University Press of Colorado, Niwot, CO.

Wells, T. C. E. 1981. Population ecology of terrestrial orchids. in The biological aspects of rare plant conservation, ed. Hugh Synge. John Wiley and Sons LTD.

Welsh, S. L., N. D. Atwood, L. C. Higgins, and S. Goodrich. 1987. A Utah flora. Great Basin Naturalist Memoir no. 9. Brigham Young University, Provo, Utah, 894 pp. 


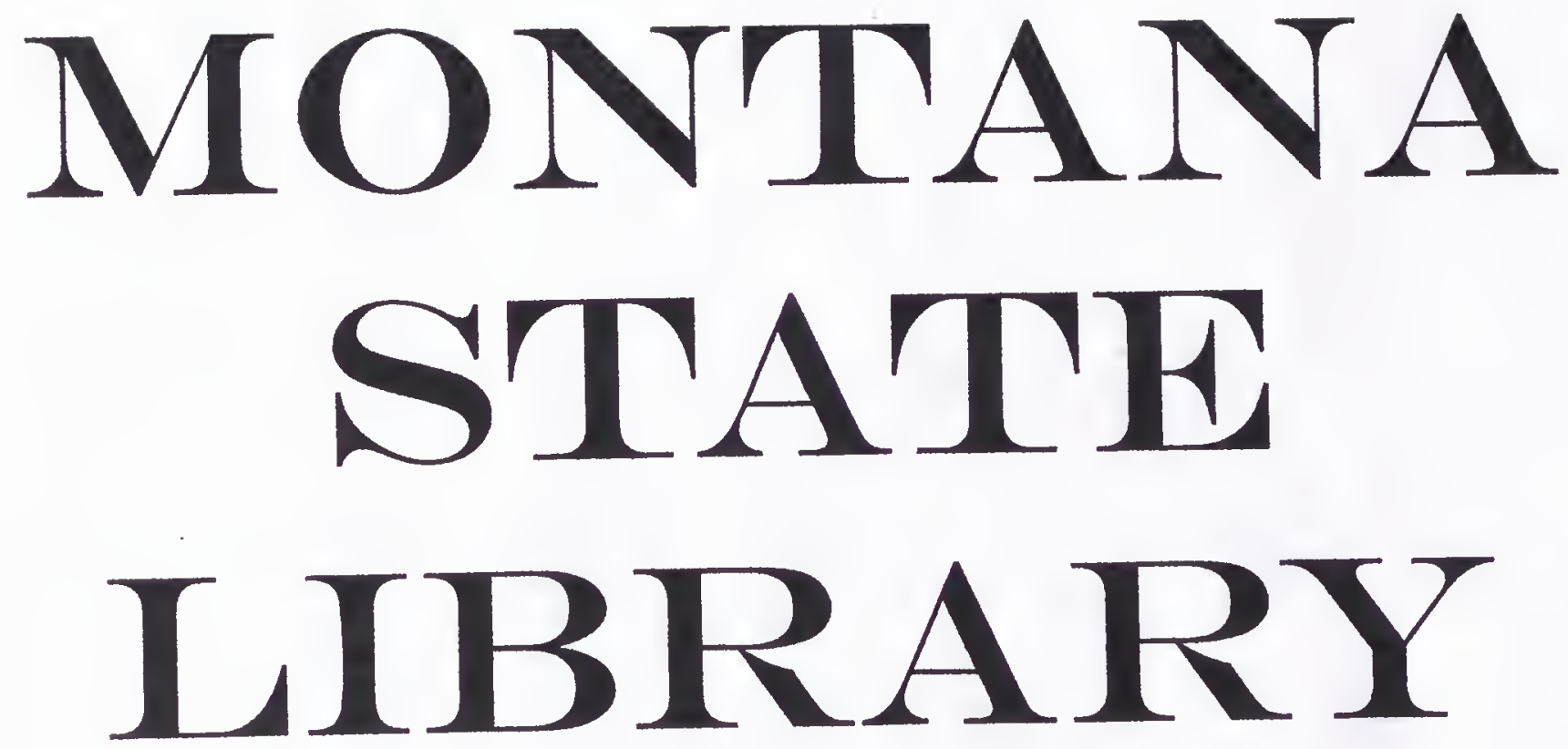

This "cover" page added by the Internet Archive for formatting purposes 